\title{
14. DOWNHOLE VARIATION OF POTASSIUM, INERT GAS ABUNDANCE, AND APPARENT K-AR AGE IN BASALTS FROM THE COSTA RICA RIFT, HOLE 504B, LEG 83, DEEP SEA DRILLING PROJECT ${ }^{1}$
}

\author{
John G. Mitchell, School of Physics, The University, Newcastle upon Tyne \\ and \\ David J. Terrell, Instituto de Geofísica, Universidad Nacional Autónoma de México²
}

\begin{abstract}
$\mathrm{Ne}, \mathrm{Ar}, \mathrm{Kr}, \mathrm{Xe}$, and $\mathrm{K}_{2} \mathrm{O}$ were measured in representative samples of holocrystalline basalt from DSDP Hole 504B. No hiatus in inert gas abundance is recognized at the base of the "oxic" alteration zone and the extent rather than the nature of alteration appears to determine these abundances. When the inert gas abundances are separately plotted against $\mathrm{K}_{2} \mathrm{O}$, two distinct trends of loss emerge, one for alteration involving $\mathrm{K}$-gain, the other for $\mathrm{K}$-loss.

Apparent whole-rock K-Ar ages are anomalous in the upper $50 \mathrm{~m}$ of basement, and below $300 \mathrm{~m}$ sub-basement. In the intervening zone of basement, celadonization adds sufficient potassium and eliminates enough "primary" ${ }^{40} \mathrm{Ar}$ early in the history of the basalts for "excess" ${ }^{40} \mathrm{Ar}$ to become subordinate to radiogenic ${ }^{40} \mathrm{Ar}$ in basalts showing potassium enrichment greater than $0.2 \%$. Stratigraphically correct $\mathrm{K}$-Ar ages are obtained, therefore, from $\mathrm{K}$-enriched basalts of the oxic alteration zone.
\end{abstract}

\section{INTRODUCTION}

We have previously reported preliminary data on inert gas abundances and apparent K-Ar ages of altered holocrystalline basalts from DSDP Holes 501, 504B, and 505B (Terrell and Mitchell, 1983). The new results reported here are all from Hole 504B (Legs 70 and 83) and extend the downhole coverage of inert gas abundances to more than $1000 \mathrm{~m}$ of basement, spanning the boundary between Layers $2 \mathrm{~B}$ and $2 \mathrm{C}$, the transition from "oxic" to "anoxic" alteration regimes occurring at $\sim 300 \mathrm{~m}$ sub-basement ( $575 \mathrm{~m}$ below sea floor [BSF]), and comprising dike and pillow lava holocrystalline samples.

In our earlier work, analyses were restricted to the "oxic alteration zone" (OAZ) of submarine weathering (Böhlke et al., 1980), the deepest sample (504B-29-1, 54$58 \mathrm{~cm}$ ) being at $210 \mathrm{~m}$ sub-basement (485 m BSF). Hubberten et al. (1983), in their geochemical study of Leg 69 and 70 samples from Hole 504B, could recognize "practically no primary chemical downhole variation." Only alteration-sensitive compounds such as $\mathrm{K}_{2} \mathrm{O}, \mathrm{H}_{2} \mathrm{O}^{+}$, $\mathrm{CO}_{2}, \mathrm{~S}, \mathrm{Tl}$, and the iron-oxidation ratio show significant variations which correlate with the mineralogical transition from the oxidative to nonoxidative zone. Subsequent studies of Leg 83 samples from the hole (Emmermann, this volume) confirm this remarkable apparent chemical uniformity, though oxygen and strontium isotopes (Barrett and Friedrichsen, 1982, 1983; Barrett, 1983) clearly distinguish the oxic/anoxic alteration transition.

We were able in our earlier study (Terrell and Mitchell, 1983) to identify an upper zone of basalts character-

\footnotetext{
${ }^{1}$ Anderson, R. N., Honnorez, J., Becker, K., et al., Init. Repts. DSDP, 83: Washington (U.S. Govt. Printing Office)

2 Addresses: (Mitchell) School of Physics, The University, Newcastle upon Tyne, NE1 7RU, United Kingdom; (Terrell) Instituto de Geofísica, Universidad Nacional Autónoma de México, México 20, D. F., México.
}

ized by anomalously high $\mathrm{K}$-Ar ages and high levels of other inert gases (particularly $\mathrm{Kr}$ and $\mathrm{Xe}$ ) which corresponds broadly with the relatively permeable "aquifer" (see Fig. 1) identified by Anderson et al. (1982) and Becker et al. (1983 this volume). Within this zone, alteration is such that olivine is occasionally preserved, and a general lack of chemical exchange with seawater is indicated by $\mathrm{K}_{2} \mathrm{O}$ contents which, at around $0.05 \%$, are little different from those of fresh basalt glass from Hole 504B (Natland et al., 1983). Below this zone, to a depth of $\sim 210 \mathrm{~m}$ sub-basement ( $485 \mathrm{~m} \mathrm{BSF}$ ), K-Ar ages consistent (though with very large errors) with the magnetic anomaly age of 5.9 m.y. (Anderson et al., 1982) were obtained from basalts that are recognized to have suffered submarine weathering, which had led to the enrichment of $\mathrm{K}_{2} \mathrm{O}$ as a consequence of celadonite formation (Honnorez et al., 1983). This zone of "acceptable" ages was also distinguished by $\mathrm{Ne}, \mathrm{Ar}, \mathrm{Kr}$, and $\mathrm{Xe}$ abundances which were, in general, a factor of two or three lower than in the upper "aquifer" zone.

The interpretation we advanced for this variation in inert gas abundances was that gases contained in the upwelling magma were partially trapped into holocrystalline cores of pillow lavas as they cooled relatively rapidly at the ocean floor. The presence of initial (or "excess") ${ }^{40} \mathrm{Ar}$ (Dalrymple and Moore, 1968; Funkhouser et al., 1968; Noble and Naughton, 1968) thus created anomalously old $\mathrm{K}-\mathrm{Ar}$ ages. In the upper zone of anomalous ages, postformational temperatures have remained below the modern equilibrium values of $60-70^{\circ} \mathrm{C}$ (Becker, Langseth, von Herzen, and Anderson, 1983). This precluded the possibility of the loss of inert gas by diffusion through the more common silicate mineral structures (in this case principally olivine, plagioclase, and clinopyroxene). In addition, low alteration prevented mineralogical changes from causing significant inert gas loss (which would also be facilitated by the presence of abun- 


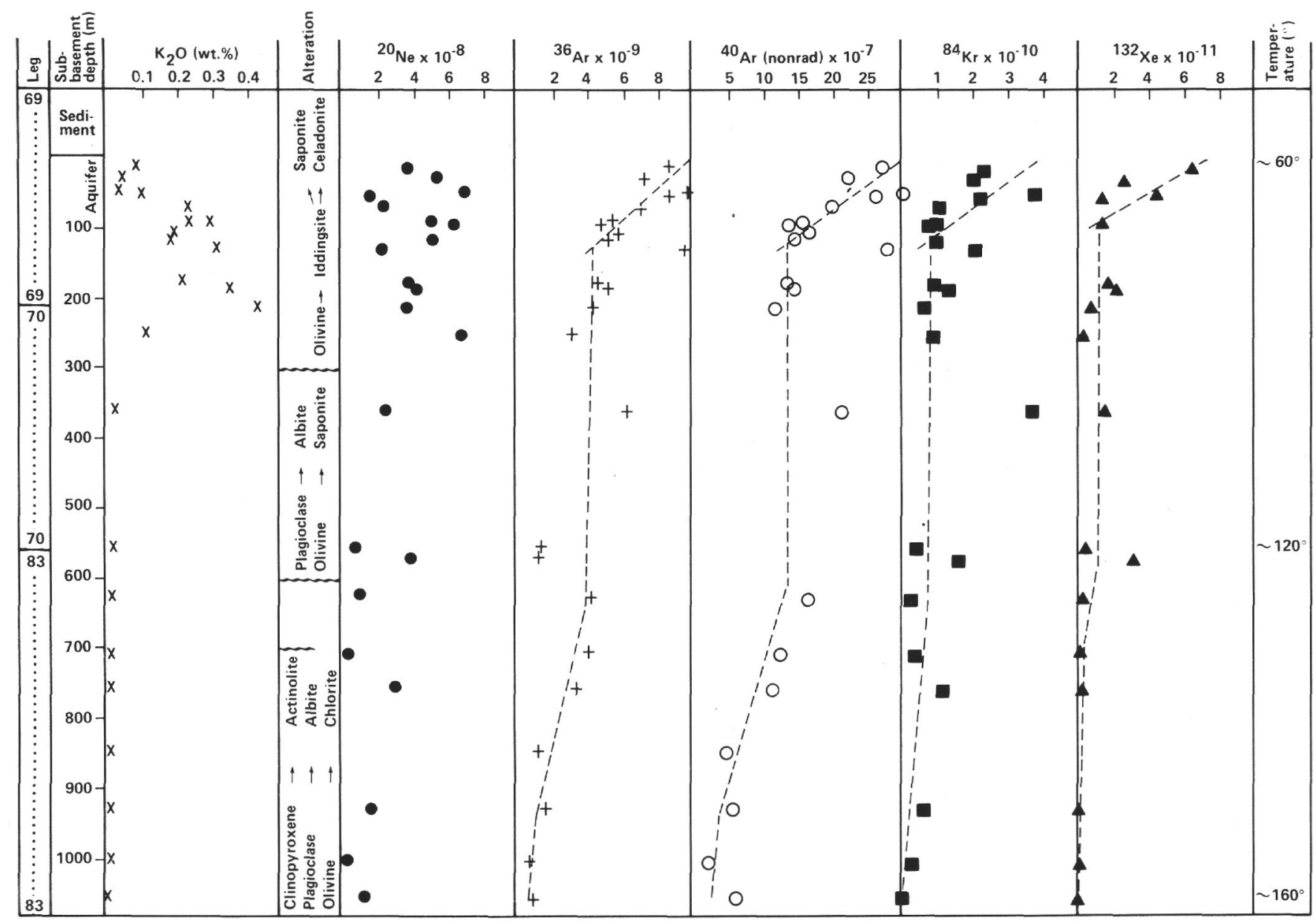

Figure 1. Downhole variation of potassium $\left(\mathrm{K}_{2} \mathrm{O}\right.$ in wt.\%) and inert gas abundance (in $\mathrm{cm}^{3} \mathrm{STP} \mathrm{g}{ }^{-1}$ ), Hole 504B, Costa Rica Rift. Note that $\mathrm{cm}^{3}$ $\mathrm{STP} / \mathrm{g}$ is the volume of inert gas in $\mathrm{cm}^{3}$ per gram of sample (reduced to standard temperature and pressure).

dant water to act as a transport agent). Fisher (1971) has argued that the exchange of rare gas between ocean floor basalts and seawater can occur at "high" (posteruptive) and at "low" (ocean floor) temperatures. A natural conclusion to be drawn from this postulate is that "correct" K-Ar ages could, in general, never be obtained from ocean floor basalts since appreciable loss of accumulating radiogenic ${ }^{40} \mathrm{Ar}$ would occur during the protracted period of time during which seawater is available to exchange rare gases with the basalt throughout its lifetime in the ocean floor. The existence of stratigraphically acceptable basalt ages from depths corresponding to temperatures of $100^{\circ} \mathrm{C}$ (Terrell and Mitchell, 1983) suggests that his proposition is not generally valid. We argued earlier that, below this anomalous age zone, recrystallization of the primary minerals during oxic alteration in the presence of abundant water (characterized by $\mathrm{K}_{2} \mathrm{O}$ values of up to $0.43 \%$ ), has led to extensive loss of those inert gases which were trapped in the rock when it first cooled. By this mechanism, valid KAr ages can be recorded in the secondary mineral assemblage. Remarkably, therefore, it appeared that the best estimate of the age of a submarine basalt would be obtained from samples showing the highest degree of (oxic) alteration, provided, of course, that the secondary mineral phases were argon-retentive at the prevailing temperatures. We were unable, in our earlier work, to recognize the "pattern" of inert gases in the altered rocks as being in any sense similar to that existing in seawater (Dymond and Hogan, 1973). In a four-element ratio plot $\left({ }^{132} \mathrm{Xe} /{ }^{84} \mathrm{Kr}\right.$ versus $\left.{ }^{36} \mathrm{Ar} /{ }^{20} \mathrm{Ne}\right)$ suggested by Saito (1978), the trend from fresh to altered rocks (assessed on the basis of potassium content) diverges from the seawater point. It was (and remains) our view that physical "mixing" is too simplistic a model for interpreting the inert gas abundance patterns in altered submarine rocks, and that a wider range of chemical and mineralogical factors exert an influence. Among them are:

1. The detailed nature of structural and chemical changes occurring in individual primary mineral phases.

2. The partition coefficients of the individual inert gases between seawater (at the temperature in question) and the secondary mineral phases.

3. The water/rock ratio, inasmuch as it determines the availability of water to act as a transporting medium for the released gases.

In presenting our new data it is possible to amplify the interpretation of the Leg 69 results in the light of chemical and mineralogical studies which have subsequently become available (Hubberten et al., 1983; Honnorez, et al., 1983). We will also attempt to incorporate those earlier data into a general account of the effect of 
alteration on inert gas abundances throughout the 1075$m$ depth of the basement section of the hole.

\section{EXPERIMENTAL METHODS}

All samples analyzed from the Leg 70 and 83 sections of Hole 504B were crushed, sieved to 5-16 mesh, washed in deionized water and dried at $110^{\circ} \mathrm{C}$. A portion of this size fraction was then pulverized in a ball mill to below 200 mesh for potassium analysis, which was performed by flame photometry using a $\mathrm{Li}$ internal standard on an EEL 450 instrument. Argon isotopic analyses were made in duplicate by fusing $\sim 2 \mathrm{~g}$ aliquots of the crushed sample at $1400^{\circ} \mathrm{C}$ in a UHV furnace using RF induction heating. The released gases were cleaned using molecular sieve, hot $\mathrm{Cu}-\mathrm{CuO}$, and $\mathrm{Ti}$ getters. Isotope dilution was by enriched ${ }^{38} \mathrm{Ar}$ "spike" and argon analyses were performed on a modified MS-10 mass spectrometer coupled directly to the extraction line and operating in the static mode (see Mitchell, 1972, for details of techniques). Conventional apparent $\mathrm{K}-\mathrm{Ar}$ ages have been calculated assuming an atmospheric ${ }^{40} \mathrm{Ar} /{ }^{36} \mathrm{Ar}$ ratio for nonradiogenic argon. Decay constants used are those recommended by Steiger and Jäger (1977).

Inert gas abundance measurements were made by fusing about 20 gm of crushed sample using the same procedures as described above. Gas analysis was performed on a modified MS-10 spectrometer (see Terrell, 1982, for details) for which the sensitivity is $\sim 10^{-4} \mathrm{~A} /$ torr with a resolution of 135 (full width at $10 \%$ maximum height). Blank corrections were in all cases less than $10 \%$ of the measured abundances and precision of measurement varied from $\pm 20 \%$ for xenon to better than $\pm 5 \%$ for ${ }^{36} \mathrm{Ar}$.

\section{PRIMARY PETROLOGY AND ALTERATION OF ANALYZED SAMPLES}

All of samples analyzed (see Table 1) were holocrystalline portions of pillow lavas or dikes. Petrologically all were fine- to medium-grained olivine + plagioclase \pm clinopyroxene phyric basalts. Minor glass, where present, occurs only in the groundmass, where it is largely altered to saponite. A full account of the alteration of the basalts is given by Alt et al. (this volume) and Honnorez et al. (1983).

Briefly, the first $300 \mathrm{~m}$ of basement shows evidence of superimposed stages of oxic and anoxic alteration which we will discuss inasmuch as alteration determines the potassium budget of the basalts. The provisional sequence of alteration (Honnorez et al., 1983) is, first, that phenocryst and groundmass olivine are replaced by "iddingsite" (predominantly mixtures of smectites and geothite), which is subsequently transformed to saponite and to celadonite or celadonite-nontronite mixtures. Andrews (1980) has suggested that saponite may be converted to celadonite in a manner similar to the vermiculite-biotite transition (as interpreted by Sahwney, 1967); that is, by way of a progressive, ordered interlayering, involving a gradual increase in the number of mica layers (and therefore K-content) through a mixed-layer series. Honnorez et al. (1983) were unable to decide whether saponite crystallized before celadonite, or vice versa. This uncertainty will not, however, influence our arguments. Plagioclase is generally unaltered (rarely replaced by magnesium-rich saponite) and clinopyroxene shows no alteration. Celadonite-nontronite is also the earliest secondary product to precipitate in the primary voids of "zero-age" submarine basalts (Honnorez, 1981) and is believed to precipitate when very low temperature hydrothermal anoxic solutions carrying $\mathrm{Si}$ and $\mathrm{Fe}$ mix with cold, oxygenated seawater impregnating the uppermost basalts before their burial by a sediment cover.
Below $300 \mathrm{~m}$, in the lower (anoxic) alteration zone, celadonite does not appear as a replacement or void-filling phase. Saponites become the dominant alteration product after olivine and (increasingly down the hole) after plagioclase. Clinopyroxene remains unaltered and this pattern of alteration persists to a sub-basement depth of approximately $600 \mathrm{~m}$.

From this point to the bottom of the hole, chlorite becomes the dominant alteration phase after olivine (though smectite and smectite-chlorite mixtures occasionally occur). Plagioclase is partly replaced by albite, chlorite, and minor laumontite, whereas clinopyroxene displays alteration rims of actinolite from below about $700 \mathrm{~m}$ sub-basement ( $975 \mathrm{~m} \mathrm{BSF}$ ). All of these features and the downhole temperature $\left({ }^{\circ} \mathrm{C}\right)($ Becker et al., this volume) are included in Figure 1.

\section{RESULTS AND DISCUSSION}

\section{Potassium}

Our potassium determinations shown in Table 1 and Figure 1 indicate that $\mathrm{K}_{2} \mathrm{O}$ values "typical" of Hole 504B basaltic glass (Natland et al., 1983) are obtained only in the upper $50 \mathrm{~m}$ or so of the basement. Our analyses differ significantly from those reported for Leg 69, where $\mathrm{K}_{2} \mathrm{O}$ values in the range 0.10 to $0.15 \%$ characterize the oxic alteration zone down to $575 \mathrm{~m}$ BSF. In this respect, Hubberten et al. (1983) obtained values of up to about $0.4 \%$ which are consistent with our studies. Below the oxic alteration zone, the $\mathrm{K}_{2} \mathrm{O}$ content diminishes systematically to values less than $0.01 \%$ in the lowest basalts (dikes) sampled. The pattern of potassium variation mirrors, we believe, the alteration processes discussed earlier. With potassium contents in celadonite from Hole 504B (Honnorez et al., 1983) averaging about $7 \% \mathrm{~K}_{2} \mathrm{O}$, it requires only about $5 \%$ alteration of the whole rock to celadonite, and/or its precipitation, to raise the wholerock $\mathrm{K}_{2} \mathrm{O}$ from $0.05 \%$ to $0.4 \%$. Abundances of $5-10 \%$ "smectites" are typical of oxic alteration zone (Barrett, 1983) and, in addition, potassium absorption to form K-rich smectites (Hart, 1973; Melson and Thompson, 1973; Seyfried and Bischoff, 1979) may also be an important process in determining the potassium budget in basalts in a manner analogous to the role of illite and glauconite in the marine sediment column. The pattern of K-gain which we recognize is almost indistinguishable from that described by Hart and Staudigel (1982).

In the zone of "anoxic" alteration, the mechanism of progressive potassium loss has been described by Hajash (1975), Bischoff and Dickson (1975), and Humphris and Thompson (1978). Their studies of "smectite," montmorillonite, and chlorite alteration products, respectively, in submarine basalts showed that $\mathrm{K}$ and $\mathrm{Ca}$ are lost and that $\mathrm{Mg}$ and $\mathrm{Na}$ are gained by basalt at temperatures over $200^{\circ} \mathrm{C}$ and pressures of 500 bar replacement of all of the primary mineral phases. The most "extreme" alteration of this kind is shown in our study by Samples 504B-130-2, 118-122 cm, and 504B-137-1, 100$104 \mathrm{~cm}$, which have lost approximately $80 \%$ of their primary potassium (assuming they had an initial $\mathrm{K}_{2} \mathrm{O}$ of $\sim 0.04 \%$, corresponding to unaltered MORB glass from Hole 504B; Natland et al., 1983). 
Table 1. Hole 504B: Downhole variation of potassium, apparent $\mathrm{K}-\mathrm{Ar}$ age, and inert gas abundances (in $\mathrm{cm}^{3} \mathrm{STP} \mathrm{g}^{-1}$ ).

\begin{tabular}{|c|c|c|c|c|c|c|c|c|c|c|}
\hline $\begin{array}{c}\text { Core- } \\
\text { Section } \\
\text { (interval in } \mathrm{cm} \text { ) }\end{array}$ & $\begin{array}{c}\text { Sub- } \\
\text { basement } \\
\text { depth } \\
\text { (m) }\end{array}$ & $\begin{array}{c}\mathrm{K}_{2} \mathrm{O} \\
\text { (wt.\%) }\end{array}$ & $\begin{array}{c}\text { Apparent } \\
\text { radiogenic } \\
40_{\mathrm{Ar} \times} \times \\
10^{-8}\end{array}$ & $\begin{array}{c}\text { Apparent }^{\mathrm{a}} \\
\text { K-Ar } \\
\text { age } \\
\text { (Ma) }\end{array}$ & $\begin{array}{c}20 \mathrm{Ne} \times \\
10^{-} 8\end{array}$ & $\begin{array}{c}36 \\
10^{-9} \times\end{array}$ & $\begin{array}{c}\text { Non- } \\
\text { radiogenic } \\
40 \mathrm{Ar} \\
10^{-7}\end{array}$ & $\begin{array}{l}{ }^{84} \mathrm{Kr} \times \\
10^{-10}\end{array}$ & $\begin{array}{c}132 \mathrm{Xe} \times \\
10^{-11}\end{array}$ & $\begin{array}{c}\mathrm{S}^{\mathrm{c}} \\
(\mathrm{ppm})\end{array}$ \\
\hline \multicolumn{11}{|l|}{ Leg 69} \\
\hline $4-4,124-127$ & 11 & 0.08 & 14.0 & $58 \pm 24$ & 3.63 & 8.64 & 26.8 & 2.33 & 6.39 & $(272)$ \\
\hline $6-2,57-60$ & 26 & 0.04 & 4.2 & $36 \pm 30$ & 5.24 & 7.38 & 22.1 & 2.06 & 2.58 & 160 \\
\hline $8-5,56-62$ & 48 & 0.03 & 15.0 & $140 \pm 40$ & 6.86 & 9.66 & 30.0 & 3.77 & 4.15 & $(891)$ \\
\hline $9-1,65-71$ & 51 & 0.10 & 12.0 & $35 \pm 17$ & 1.55 & 8.60 & 26.4 & 2.15 & 1.29 & 547 \\
\hline $11-1,74-80$ & 69 & 0.23 & 2.3 & $3 \pm 3$ & 2.30 & 6.96 & 20.2 & 1.04 & BDL & 300 \\
\hline $13-3,33-38$ & 90 & 0.23 & 6.3 & $8 \pm 3$ & 4.96 & 5.39 & 15.5 & 0.92 & 1.40 & $(180)$ \\
\hline $13-3,132-139$ & 91 & 0.29 & 9.3 & $10 \pm 5$ & 6.27 & 4.75 & 13.6 & 0.76 & BDL & (180) \\
\hline $15-2,136-142$ & 103 & 0.19 & 3.0 & $5 \pm 4$ & 17.05 & 5.78 & 16.7 & 0.92 & BDL & 138 \\
\hline $16-5,27-36$ & 115 & 0.18 & 6.1 & $10 \pm 4$ & 5.13 & 5.13 & 14.9 & 0.97 & BDL & (75) \\
\hline $19-1,5-8$ & 128 & 0.31 & 12.0 & $12 \pm 7$ & 2.12 & 9.64 & 28.0 & 2.02 & BDL & 559 \\
\hline $24-2,100-105$ & 176 & 0.21 & 5.5 & $8 \pm 3$ & 3.85 & 4.69 & 13.5 & 0.94 & 1.96 & ND \\
\hline $25-2,69-76$ & 184 & 0.35 & 6.1 & $5 \pm 2$ & 4.24 & 5.11 & 14.5 & 1.63 & 2.30 & 173 \\
\hline $29-1,54-58$ & 210 & 0.43 & 6.2 & $4 \pm 2$ & 3.60 & 4.29 & 11.9 & 0.52 & 0.77 & 163 \\
\hline \multicolumn{11}{|l|}{ Leg 70} \\
\hline $33-1,41-44$ & 244 & ND & ND & ND & 6.83 & 3.11 & ND & 0.86 & 0.31 & 191 \\
\hline $47-1,7-11$ & 364 & 0.024 & 28.6 & $340 \pm 60$ & 2.49 & 6.26 & 21.4 & 3.70 & 1.48 & \\
\hline $69-1,106-112$ & 552 & ND & ND & ND & 0.69 & 1.51 & ND & 0.38 & 0.36 & \\
\hline \multicolumn{11}{|l|}{ Leg 83} \\
\hline $72-3,30-32$ & 571 & ND & ND & ND & 3.90 & 1.38 & ND & 1.64 & 3.17 & \\
\hline $78-2,115-119$ & 625 & 0.019 & 38.4 & $540 \pm 60$ & 0.91 & 4.30 & 16.6 & 0.22 & 0.21 & \\
\hline $88-1,30-34$ & 702 & 0.019 & 4.4 & $70 \pm 15$ & 0.37 & 4.19 & 12.8 & 0.38 & 0.05 & \\
\hline $94-1,19-23$ & 756 & 0.009 & 10.5 & $330 \pm 50$ & 3.18 & 3.61 & 11.7 & 1.20 & 0.20 & \\
\hline $104-3,2-5$ & 844 & 0.012 & 10.7 & $260 \pm 50$ & ND & 1.36 & 5.1 & ND & ND & \\
\hline $118-1,7-11$ & 920 & 0.012 & 5.8 & $140 \pm 20$ & 1.79 & 1.80 & 5.9 & 0.69 & 0.10 & \\
\hline $130-2,118-122$ & 1006 & 0.005 & 4.5 & $260 \pm 60$ & 0.41 & 0.81 & 2.9 & 0.30 & 0.10 & \\
\hline $137-1,100-104$ & 1054 & 0.008 & 38.5 & $1100 \pm 150$ & 1.35 & 1.01 & 6.8 & 0.02 & 0.05 & \\
\hline
\end{tabular}

Note: ND Not determined.

${ }^{a}$ Apparent $\mathrm{K}-\mathrm{Ar}$ age calculated assuming an atmospheric nonradiogenic ${ }^{40} \mathrm{Ar} /{ }^{36} \mathrm{Ar}$ ratio and decay constants of Steiger and Jäger (1977).

b "Nonradiogenic" ${ }^{40} \mathrm{Ar}$ calculated as $40 \mathrm{Ar}_{\text {total }}-\mathrm{K}_{2} \mathrm{O} \times\left(2 \times 10^{-7}\right)$

c Sulfur data from Hubberten et al., 1983. Data in parentheses are from core sections adjacent to one analyzed here.

\section{Degree of Alteration and Inert Gas Abundances}

Hubberten et al. (1983) have pointed to the remarkable uniformity of major element abundances throughout Hole 504B, singling out potassium as being the only major element oxide to show a significant change in concentration at the base of the oxic alteration zone. Strontium, rubidium, ${ }^{87} \mathrm{Sr} /{ }^{86} \mathrm{Sr}, \delta^{18} \mathrm{O}$ (Barrett, 1983; Barrett and Friedrichsen, 1982, 1983) $\mathrm{S}, \mathrm{Tl}, \mathrm{H}_{2} \mathrm{O}^{+}, \mathrm{CO}_{2}$ and iron-oxidation ratio (Hubberten et al., 1983), all show discontinuities at $\sim 300 \mathrm{~m}$ sub-basement (575 m BSF) which have been related to a flux of seawater which was open to exchange with the ocean. The abundances of ${ }^{36} \mathrm{Ar},{ }^{40} \mathrm{Ar}$ (nonradiogenic), ${ }^{84} \mathrm{Kr}$, and ${ }^{132} \mathrm{Xe}$ (see Fig. 1) all show a reduction by a factor of approximately two in the upper $100 \mathrm{~m}$ of the basement. Below this level we recognize a generally uniform level of inert gas abundance until $600 \mathrm{~m}$ sub-basement ( $875 \mathrm{~m} \mathrm{BSF}$ ) is reached. Below this point inert gas abundances (with the exception of ${ }^{20} \mathrm{Ne}$ ) become progressively lower toward the bottom of the hole. In particular, there is no hiatus in the abundance variations at $300 \mathrm{~m}$ sub-basement $(575 \mathrm{~m}$ BSF), which leads us to conclude that seawater-dissolved gases are not a factor in determining the variation observed here. The degree of alteration (in the presence of abundant water, be it open or closed circulation) appears to control the process of inert gas loss.
To demonstrate this proposed relationship between degree of alteration and inert gas loss, we have compiled Figure 2, which plots abundance of each gas isotope (measured in $\mathrm{cm}^{3} \cdot \mathrm{g}^{-1}$ ) versus $\mathrm{K}_{2} \mathrm{O}$. The variation is plotted logarithmically to accommodate a variation of a factor of nearly 100 in $\mathrm{K}_{2} \mathrm{O}$. It is significant, we believe, that those basalts having $\mathrm{K}_{2} \mathrm{O}$ contents nearest to unaltered MORB glass from Hole 504B $\left(\mathrm{K}_{2} \mathrm{O} \sim 0.04 \%\right.$, represented by Samples 504B-6-2, 57-60 cm, and 504B-8-5, 56$62 \mathrm{~cm}$ ), also possess the highest inert gas abundances, which we argue to be most representative of primary solidified holocrystalline basalt (though not necessarily of primary magma, since these more slowly cooled interiors of pillows will experience significant degassing both during and immediately following crystallization; Fisher, 1971). Progressive saponitization and chloritization of olivine, which is accompanied by albitization of plagioclase below $300 \mathrm{~m}$ sub-basement ( $575 \mathrm{~m} \mathrm{BSF}$ ) and alteration of clinopyroxene below $700 \mathrm{~m}$ sub-basement (975 m BSF), has led to the release of each of the inert gases whose losses are broadly in proportion to the loss of $\mathrm{K}_{2} \mathrm{O}$ (arrows indicated in Fig. 2, beginning at the mean of 504B-6-2, 57-60 cm and 504B-8-5, 56-62 cm, and with slope +1 ) down to over $80 \%$ potassium loss. Since seawater in equilibrium with the atmosphere at $20^{\circ} \mathrm{C}$ contains factors of $10^{3}$ more ${ }^{36} \mathrm{Ar}, 10^{2}$ more ${ }^{84} \mathrm{Kr}$ and ${ }^{132} \mathrm{Xe}$, and 10 more ${ }^{20} \mathrm{Ne}$ than an equal mass of 


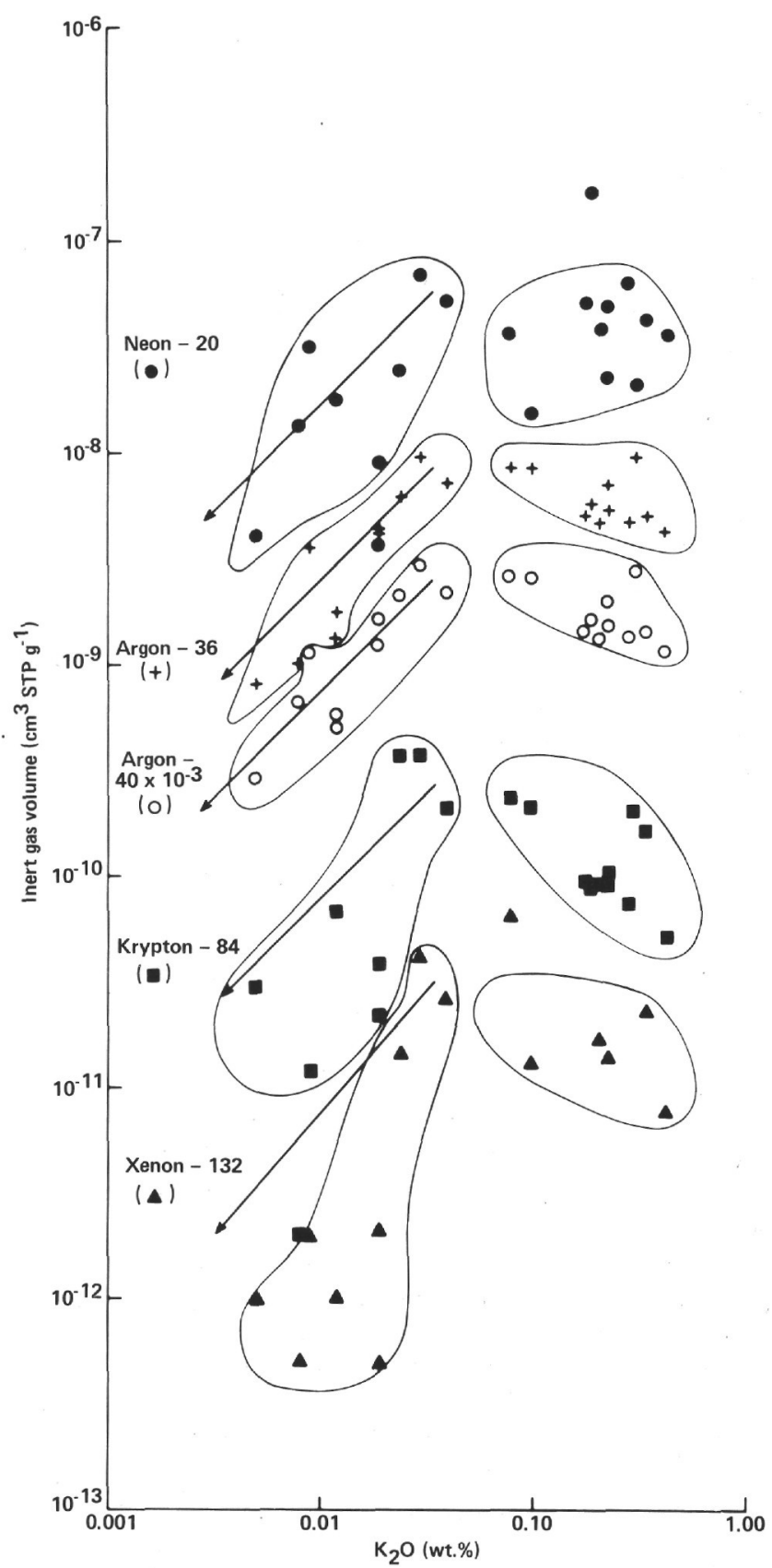

Figure 2. Trends of inert gas loss during alteration involving potassium gain and loss. Arrows represent hypothetical trend of proportional $(1: 1)$ loss of $\mathrm{K}_{2} \mathrm{O}$ and inert gases.

MORB (Bieri et al., 1966), removal of inert gases from basalt, especially with water/rock ratios in excess of unity, will scarcely change the rare gas abundances in the water. In a partition process which evidently favors the water phase (since gases are lost from the rocks) the water will be expected to act as an infinite reservoir for released gas.

Figure 2 also shows that the variation of inert gas abundance during alteration involving potassium gain clearly does not follow the same trend. The three processes we distinguished earlier as contributing to potassium uptake are, however, compatible with the observed trend. Early formation of iddingsite after olivine will cause loss of those inert gases occurring in olivine, and be accompanied by a small increase in the whole-rock $\mathrm{K}_{2} \mathrm{O}$ (Honnorez et al., 1983, cite $\mathrm{K}_{2} \mathrm{O}$ contents of iddingsite in the range $0.1 \%$ to $0.5 \%$ ). It is evident that this loss of inert gas should correlate with the abundance of alteration products after olivine, for which we have no data from our particular samples. Figures of up to $20 \%$ olivine (phenocryst + groundmass) are typical for basalts from Hole 504B and alteration of olivine varies from "slight" to "total" in the upper $200 \mathrm{~m}$ (Honnorez et al., 1983).

Loss of each inert gas is virtually constant at $\sim 50 \%$ (see Fig. 2) in the interval when potassium increases from $\mathrm{K}_{2} \mathrm{O}=0.15$ to $0.43 \%$. We interpret this as an expression of the fact that potassium is added over this range in processes which involve only secondary minerals, which, of necessity, have already lost their inert gases in the processes that led to their formation. Such processes include the conversion of iddingsite (after olivine) to celadonite and celadonite-nontronite, absorption of potassium into K-rich smectites, and precipitation of celadonite in voids, which naturally adds $\mathrm{K}_{2} \mathrm{O}$ without disturbing the inert gases. The overall effect is the flat trend of inert gas abundance for $\mathrm{K}_{2} \mathrm{O}$, increasing from 0.15 to $0.43 \%$ (see Fig. 2).

It is tempting to seek a chemical parameter (other than $\mathrm{K}_{2} \mathrm{O}$, which clearly plays a special role in low-temperature alteration) that is associated only with the transformation of olivine to iddingsite, and that might, as a consequence, be correlated with inert gas abundance throughout the zone of oxic alteration. Most of the major elements, which are likely to change dramatically in the transformation, also undergo absorption on clays or precipitation as oxides or hydroxides, including $\mathrm{Fe}, \mathrm{Mn}$, and $\mathrm{Mg}$. We have unsuccessfully attempted to correlate inert gas loss with each of the essential elements, with $\mathrm{H}_{2} \mathrm{O}^{+}$, and with seismic velocity (Hart, 1973).

In Figure 3 we have plotted inert gas concentration in the oxic alteration zone against sulfur, which appears to be low in basalts of this zone (Hubberten et al., 1983) (pyrite exists only in samples from below $300 \mathrm{~m}$ subbasement [ $575 \mathrm{~m} \mathrm{BSF}]$ ). The diagram is remarkable for the opposite trend which is displayed by ${ }^{20} \mathrm{Ne}$ relative to the other gases. In Figure 2 (versus $\mathrm{K}_{2} \mathrm{O}$ ) the Ne abundance is the most scattered of all the inert gases we measured whereas in Figure 3 (versus S) (data from Hubberten et al., 1983) for samples from identical and neighboring core sections, ${ }^{20} \mathrm{Ne}$ shows a monotonic increase as sulfur decreases, but the heavier inert gases decrease with decreasing sulfur. Andrews (1979) and Krause et al. (1977) have pointed out that S contents in Layer 2 basalts can be highly erratic, even within the same core section and from sample locations only millimeters apart. Future studies which attempt such a correlation of inert gas and major or minor element abundances must clearly pay greater attention to such detail than was possible in our retrospective interpretation of our inert gas data, which depended on independent chemical analyses performed in other laboratories. The loss of sulfur witnessed here is presumably a consequence of sulfur oxi- 


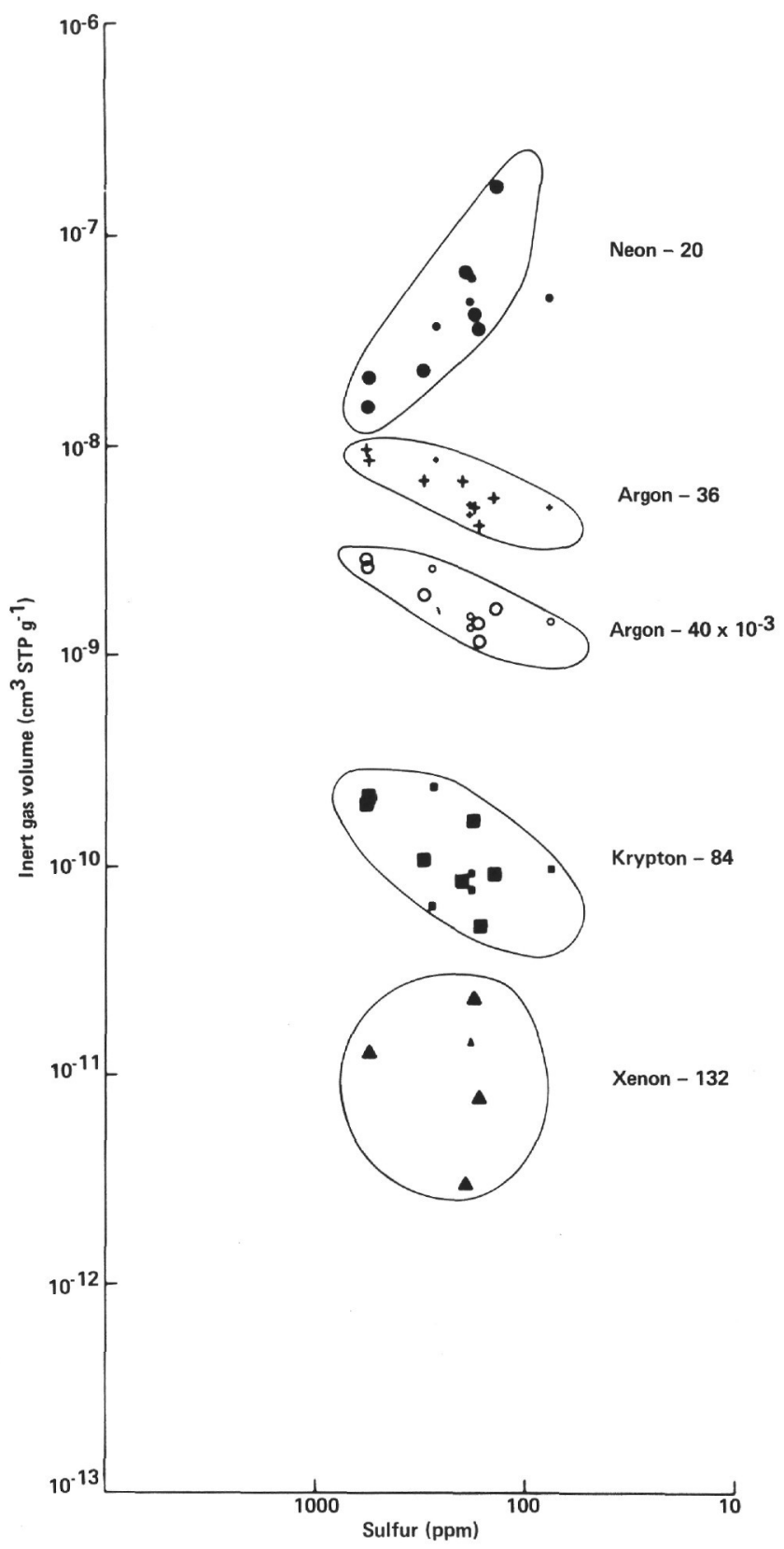

Figure 3. Trend of inert gas loss during alteration involving sulfur loss in the oxic alteration zone. Large symbols denote analysis of sulfur on same core section; where this is not available, small symbols are analyses of sulfur on core section closest to one in which inert gases were measured (Hubberten et al., 1983).

dation and dissolution in seawater as sulfate ions, so that this trend of inert gas loss is an expression of the degree of basalt oxidation, as is also the case with early loss of potassium in iddingsitization. With the exception of neon, inert gases are lost as sulfur is oxidized and dissolved during alteration. Why neon should partition into the rock is not yet understood. The atomic radius of neon $(1.1 \AA)$ is significantly smaller than those of the heavier inert gases $(\mathrm{Ar}=1.6 \AA, \mathrm{Kr}=1.7 \AA, \mathrm{Xe}=1.9$ $\AA$ ) and compares closely with the ionic radius of many of the interlayer and linking ions (e.g., $\mathrm{Ca}^{2+}, \mathrm{K}^{+}$,
$\mathrm{Mg}^{2+}$ ) of many primary silicate minerals and their common alteration products. This may facilitate its selective incorporation into secondary phases. In addition, it has been shown that at temperatures below $80^{\circ} \mathrm{C}$ it is not possible to pack more than a limited number of water molecules round small, inert gas atoms (Eley, 1939), a phenomenon which also finds expression in the low solubility of neon and helium in water at those temperatures, compared to the heavier inert gases. On both these counts, the partition of neon might indeed favor the alteration products rather than water, in which neon is abundant relative to basalt and could as a consequence act as a source for the neon enrichment in the rock phase.

\section{K-Ar Ages}

The inert gas variations down the hole assist our interpretation of the $\mathrm{K}-\mathrm{Ar}$ age changes occurring in the cores. If we examine the ${ }^{40} \mathrm{Ar}$ budgets of Samples 504B$6-2,57-60 \mathrm{~cm}$, and 504B-8-2, 56-62 cm, which we believe on geochemical grounds to be the least disturbed basalts, then their true radiogenic ${ }^{40} \mathrm{Ar}$ contents (given their present $\mathrm{K}_{2} \mathrm{O}$ contents and an age of $\sim 6 \mathrm{Ma}$ ) are $0.8 \times 10^{-8}$ and $0.6 \times 10^{-8} \mathrm{~cm}^{3} \cdot \mathrm{g}^{-1}$. Assuming that the measured ${ }^{36} \mathrm{Ar}$ is associated with ${ }^{40} \mathrm{Ar}$ by a near-atmospheric ratio, their respective levels of "excess" ${ }^{40} \mathrm{Ar}$ may be deduced from the apparent radiogenic ${ }^{40} \mathrm{Ar}$ content (Table 1) to be $3.4 \times 10^{-8}$ and $14.4 \times 10^{-8} \mathrm{~cm}^{3}$. $\mathrm{g}^{-1}$. We recognize that during olivine replacement $\sim 50 \%$ of primary gases were lost $\left({ }^{36} \mathrm{Ar},{ }^{84} \mathrm{Kr}\right.$, and $\left.{ }^{132} \mathrm{Xe}\right)$, so that after a similar proportion of "excess" ${ }^{40} \mathrm{Ar}$ had been lost, the "excess" ${ }^{40} \mathrm{Ar}$ abundances in altered samples are typically $1.7 \times 10^{-8}$ or $7.2 \times 10^{-8} \mathrm{~cm}^{3} \cdot \mathrm{g}^{-1}$. When the potassium content is raised in the deeper samples (504B-9-1, 65-71 cm to 504B-29-1, 54-58 cm) by celadonite formation and possible $\mathrm{K}$-absorption, to a level of typically $0.25 \%\left(\mathrm{~K}_{2} \mathrm{O}\right)$, the true radiogenic argon accumulation over a period of $6 \mathrm{Ma}$ would be $5 \times 10^{-8}$ $\mathrm{cm}^{3} \cdot \mathrm{g}^{-1}$. It is evident that the residual volumes of "excess" ${ }^{40} \mathrm{Ar}$ in these celadonite-bearing basalts would increase the apparent conventional $\mathrm{K}-\mathrm{Ar}$ age by up to about a factor of two, which is precisely the maximum age discrepancy we recognize in our data. The existence of a zone of geologically "acceptable" ages encourages us to speculate that at low temperatures $\left(<100^{\circ} \mathrm{C}\right)$ celadonite behaves as an argon-retentive phase over time scales of millions of years. This may encourage further $\mathrm{K}$-Ar studies of this mineral in other samples of basalts which have suffered "submarine weathering" (see also Sturt et al., 1979, for evidence of celadonite argon retentivity in a nonoceanic environment). We find no mineralogical evidence to suggest that $\mathrm{K}$-feldspar alteration after plagioclase is a significant factor in determining the K-Ar ages of our samples (Ozima et al., 1977).

Interpretation of the $\mathrm{K}-\mathrm{Ar}$ isotopic ages in the zone of anoxic alteration is considerably more complicated. All of the apparent conventional K-Ar ages obtained are up to two orders of magnitude too large and have no geological significance. A calculation similar to that done for the celadonite-bearing rocks shows that in samples which have lost typically $75 \%$ of their primary inert gas- 
es (and, by implication, "excess" ${ }^{40} \mathrm{Ar}$ ), residual levels of "excess" ${ }^{40} \mathrm{Ar}$ (based on Samples 504B-6-2, 57-60 cm and 504B-8-5, 56-62 cm as starting datum) will be 0.8 and $3.6 \times 10^{-8} \mathrm{~cm}^{3} \cdot \mathrm{g}^{-1}$, respectively. With a $\mathrm{K}_{2} \mathrm{O}$ of typically $0.01 \%$, radiogenic argon accumulation would be $0.2 \times 10^{-8} \mathrm{~cm}^{3} \cdot \mathrm{g}^{-1}$ in $6 \mathrm{Ma}$. It would be possible in this way to account for anomalous apparent ages which were greater by a factor of 10 , but not a factor of 100 .

A number of factors offer themselves as candidates to account for the discrepancy in "excess" ${ }^{40} \mathrm{Ar}$ abundance. First, the intrusive style of the rocks, compared to their extrusive counterparts, may have produced a level of postcooling "excess" ${ }^{40} \mathrm{Ar}$ that is higher in the dikes than in pillow lavas. Among our analyses we have only one example of a pillow lava and neighboring dike (504B$69-1,106-112 \mathrm{~cm}$ and 504B-72-3, 30-32 cm, respectively, separated by $20 \mathrm{~m}$ ) which have, as a consequence of their proximity, suffered a similar degree of alteration. ${ }^{20} \mathrm{Ne},{ }^{84} \mathrm{Kr}$, and ${ }^{132} \mathrm{Xe}$ are all higher in the dike $(504 \mathrm{~B}-$ $72-3,30-32 \mathrm{~cm}$ ) by a factor of between 4 and 8 , which supports a case for higher postcooling inert gas abundances in dikes in general. Regrettably, none of the pillow lava units below 504B-69-1, 106-112 cm have been examined in this study. Secondly, closed-system water circulation may be a contributory factor. Water in the "closed" anoxic alteration zone would have become progressively enriched in ${ }^{40} \mathrm{Ar}$ as primary "excess" gases were released by alteration of primary mineral phases. Clauer (1981) has shown that during subaerial weathering of biotite by groundwater, argon of atmospheric ${ }^{40} \mathrm{Ar} /{ }^{36} \mathrm{Ar}$ is taken up from water in the neoforming clay mineral alteration products. It is possible that an analogous process occurred in the deeper sections of Hole $504 \mathrm{~B}$, and that argon of above-atmospheric ${ }^{40} \mathrm{Ar} /{ }^{36} \mathrm{Ar}$ ratio was taken up from water into the later-forming alteration phases. As has been pointed out by Hart (1973), greenschist metamorphism may take place in two stages. First, albite and actinolite are produced from plagioclase and pyroxene near the ridge crest at temperatures around $300^{\circ} \mathrm{C}$. This is followed by a second stage taking place at low temperatures and occurring progressively with distance from the ridge crest, in which secondary chlorite is formed.

The whole question of inert gas abundances in basalts of the oxic alteration zone is, in any case, subject to the uncertainties arising from our inadequate knowledge concerning the inert gas retentivities of the various alteration products at temperatures which are currently in excess of $100^{\circ} \mathrm{C}$. Argon retentivity can clearly vary widely among the various sheet silicate structures. Chlorite is inferior to muscovite during mesothermal processes (Shepherd et al., 1976), whereas kaolinite (as an extreme example) has been shown to behave as an open system for $\mathrm{K}$ and $\mathrm{Ar}$ exchange at temperatures estimated to be $120^{\circ} \mathrm{C}$ (Sturt et al., 1979). The likelihood seems that the environment at these temperatures may be one of an equilibrium of element and isotopic exchange, because water studies (Mottl et al., 1983) show that major element exchange takes place within hours of the introduction of ocean water during drilling. The progressive reduction of inert gas abundance down the hole may thus be a consequence of partition coefficients which increasingly favor the water at increasing temperature. An analogy may exist with inert gas solubilities in water, where modification to the water structure is believed to determine the monotonic increase in solubility with temperature above $80^{\circ} \mathrm{C}$.

\section{CONCLUSIONS}

Downhole inert gas abundances diminish generally with increasing depth, but show no hiatus at the transition between the oxic (open-system water circulation) and anoxic (closed-system water circulation) alteration zones, which is distinguished at $\sim 300 \mathrm{~m}$ sub-basement $(575 \mathrm{~m}$ BSF) by contrasting $\mathrm{K}, \mathrm{H}_{2} \mathrm{O}^{+}, \mathrm{S}, \mathrm{Sr},{ }^{87} \mathrm{Sr} /{ }^{86} \mathrm{Sr}$ and $\delta^{18} \mathrm{O}$ values. Two distinct trends of inert gas loss are recognized relative to the highest abundances, which are recorded on pillows from the "aquifer" zone.

1. In the oxic alteration zone down to $\sim 300 \mathrm{~m}$ subbasement ( $575 \mathrm{~m}$ BSF), celadonite formation after olivine and celadonite precipitation produce a loss of up to about $50 \%$ of primary gases, which is sufficient (when accompanied by an increase of whole-rock $\mathrm{K}_{2} \mathrm{O}$ of up to $0.4 \%$ ) to reduce the influence of magmatic "excess" $40 \mathrm{Ar}$ to a level whereby "correct" conventional K-Ar ages are obtained. Sulfur abundances show a strong correlation with inert gas abundance, depletion of sulfur by uptake in seawater being associated with a loss of $\mathrm{Ar}, \mathrm{Kr}$, and $\mathrm{Xe}$. Neon appears to be enriched in the rock during this process, suggesting that the partition coefficient for neon may favor the alteration phases rather than water (in contrast to the other three gases studied) at these low temperatures.

2 . In the anoxic alteration zone which follows downward, progressive smectitization, chloritization, albitization, and actinolite formation after pyroxene steadily reduce the inert gas abundances in an almost 1:1 fashion with decreasing $\mathrm{K}_{2} \mathrm{O}$, to below $10 \%$ of their postcooling abundances. The immediate postcooling abundances may, however, be significantly higher in the dikes than in the pillow lavas. Apparent $\mathrm{K}-\mathrm{Ar}$ ages in this zone are significantly disturbed by residual "excess" ${ }^{40} \mathrm{Ar}$, and the downhole temperatures may, in any case, be high enough for alteration products to behave as open systems for $\mathrm{K}$ and Ar exchange. The measured abundances may, therefore, reflect the temperature dependence of partition coefficients between alteration phases and water, as much as the degree of alteration.

\section{ACKNOWLEDGMENTS}

We would like to thank Joe Cann, David Fisher, Keir Becker, and an anonymous reviewer for their constructive criticism of our manuscript. Rob Ridley's technical support in mass spectrometry was invaluable and discussions with Joe Cann and Andy Adamson were, throughout our study, both stimulating and fruitful.

\section{REFERENCES}

Anderson, R. N., Honnorez, J., Becker, K., Adamson, A. C., Alt, J. C., et al., 1982. DSDP Hole 504B, the first reference section over 1 $\mathrm{km}$ through Layer 2 of the oceanic crust. Nature, 300:589-594.

Andrews, A. J., 1979. On the effect of low-temperature seawater-basalt interactions on the distribution of sulphur in oceanic crust, Layer 2. Earth Planet. Sci. Lett., 46:68-80. 
1980. Saponite and celadonite in Layer 2 basalts, DSDP Leg 37. Contrib. Mineral. Petrol., 73:323-340.

Barrett, T. J., 1983. Strontium- and lead-isotope composition of some basalts from Deep Sea Drilling Project Hole 504B, Costa Rica Rift, Legs 69 and 70. In Cann, J. R., Langseth, M. G., Honnorez, J., Von Herzen, R. P., White, S. M., et al., Init. Repts. DSDP, 69: Washington (U.S. Govt. Printing Office), 643-650.

Barrett, T. J., and Friedrichsen, H., 1982. Strontium and oxygen isotopic composition of some basalts from Hole 504B, Costa Rica Rift, DSDP Legs 69 and 70. Earth Planet. Sci. Lett., 60:27-38.

1983. Oxygen- and hydrogen-isotope composition of some basalts from Deep Sea Drilling Project Hole 504B, Costa Rica Rift, Legs 69 and 70. In Cann, J. R., Langseth, M. G., Honnorez, J., Von Herzen, R. P., White, S. M., et al., Init. Repts. DSDP, 69: Washington (U.S. Govt. Printing Office), 637-642.

Becker, K., Langseth, M., and Von Herzen, R. P., 1983. Deep crustal geothermal measurements, Hole 504B, Deep Sea Drilling Project Legs 69 and 70. In Cann, J. R., Langseth, M. G., Honnorez, J., Von Herzen, R. P., White, S. M., et al., Init. Repts. DSDP, 69: Washington (U.S. Govt. Printing Office), 223-236.

Becker, K., Langseth, M. G., Von Herzen, R. P., and Anderson, R. N., 1983. Deep crustal geothermal measurements, Hole 504B, Costa Rica Rift. J. Geophys. Res., 88:3447-3457.

Bieri, R. H., Koide, M., and Goldberg, E. D., 1966. The noble gas content of Pacific seawaters. J. Geophys. Res., 71:5243-5265.

Bischoff, J. L., and Dickson, F. W., 1975. Seawater-basalt interaction at $200^{\circ} \mathrm{C}$ and 500 bars: Implications for the origin of sea-floor heavy metal deposits and regulation of seawater chemistry. Earth Planet. Sci. Lett., 25:385-397.

Böhlke, J. K., Honnorez, J., and Honnorez,-Guerstein, B-M., 1980. Alteration of basalts from Site 396B, DSDP; petrographic and mineralogic studies Contrib. Mineral. Petrol., 73:341-364.

Clauer, N., 1981. Strontium and argon isotopes in naturally weathered biotites, muscovites and feldspars. Chem. Geol., 31:325-334.

Dalrymple, G. B., and Moore, J. G., 1968. Argon 40: Excess in submarine pillow basalts from Kilauea Volcano, Hawaii. Science, 161: 1132-1135.

Dymond, J., and Hogan, L., 1973. Noble gas abundance patterns in deep-sea basalts-primordial gases from the mantle. Earth Planet. Sci. Lett., 20:131-139.

Eley, D. D., 1939. On the solubility of gases, Part I. The inert gases in water. Trans. Faraday Soc., 35:1281-1293.

Fisher, D. E., 1971. Incorporation of argon in East Pacific basalts. Earth Planet. Sci. Lett., 12:321-324.

Funkhouser, J. G., Fisher, D. E., and Bonatti, E., 1968. Excess argon in deep-sea rocks. Earth Planet. Sci. Lett., 5:95-100.

Hajash, A., 1975. Hydrothermal processes along mid-ocean ridges: An experimental investigation. Contrib. Mineral. Petrol., 53: 205-226.

Hart, R. A., 1973. A model for chemical exchange in the basalt-seawater system of Oceanic Layer 2. Can. J. Earth Sciences, 10: 799-816.

Hart, S. R., and Staudigel, H., 1982. The control of alkalies and uranium in sea-water by ocean crust alteration. Earth Planet. Sci. Lett., $58: 202-212$.

Honnorez, J., 1981. The aging of the oceanic crust at low temperature. In Emiliani, C. (Ed.), The Sea (Vol. 7): New York (John Wiley and Sons), 525-587.

Honnorez, J., Laverne, C., Hubberten, H-W., Emmerman, R., and Muehlenbachs, K., 1983. Alteration processes in Layer 2 basalts from Deep Sea Drilling Project Hole 504B, Costa Rica Rift. In Cann, J. R., Langseth, M. G., Honnorez, J., Von Herzen, R. P., White, S. M., et al., Init. Repts. DSDP, 69: Washington (U.S Govt. Printing Office), 509-546.
Hubberten, H-W., Emmerman, R., and Puchelt, H., 1983. Geochemistry of basalts from Cost Rica Rift Sites 504 and 505 (Deep Sea Drilling Project Legs 69 and 70). In Cann, J. R., Langseth, M. G., Honnorez, J., Von Herzen, R. P., White, S. M., et al. Init. Repts. DSDP, 69: Washington (U.S. Govt. Printing Office), 791-803.

Humphris, S. E., and Thompson, G., 1978. Hydrothermal alteration of oceanic basalts by sea-water. Geochim. Cosmochim. Acta, 42: 107-115.

Krause, H. R., Brown, H. M., and Farquharson, R. B., 1977. Sulfur isotope compositions of sulfides and sulfates, DSDP Leg 37. Can. J. Earth Sci., 14:787-793.

Melson, W. G., and Thompson, G., 1973. Glassy abyssal basalts, Atlantic sea floor near St. Paul's Rocks. Petrography and composition of secondary clay minerals. Geol. Soc. Am. Bull., 84: 703-716.

Mitchell, J. G., 1972. Potassium-argon ages from the Cheviot Hills, Northern England. Geol. Mag., 109:421-426.

Mottl, M. J., Anderson, R. N., Jenkins, W. J., and Lawrence, J. R., 1983. Chemistry of waters sampled from basaltic basement in Deep Sea Drilling Project Holes 501, 504B, and 505B. In Cann, J. R., Langseth, M. G., Honnorez, J., Van Herzen, R. P., White, S. M., et al., Init. Repts, DSDP, 69: Washington (U.S. Govt. Printing Office), 475-483.

Natland, J. H., Adamson, A. C., Laverne, C., Melson, W. G., and O'Hearn, T., 1983. A compositionally nearly steady-state magma chamber at the Costa Rica Rift: Evidence from basalt glass and mineral data, Deep Sea Drilling Project Sites 501, 504, and 505. In Cann, J. R., Langseth, M. G., Honnorez, J., Von Herzen, R. P., White, S. M., et al., Init. Repts. DSDP, 69: Washington (U.S. Govt. Printing Office), 811-858.

Noble, C. S., and Naughton, J. J., 1968. Deep ocean basalts: Inert gas content and uncertainties in age dating. Science, 162:265-267.

Ozima, M., Saito, K., and Honda, M., 1977. Sea water weathering effect on K-Ar age of submarine basalts. Geochim. Cosmochim. Acta, 41:453-461.

Saito, K., 1978. Classification of rare gases. In Alexander, E. C., Jr., and Ozima, M. (Eds.) Terrestrial Rare Gases: Tokyo (Cent. Acad. Publ. Japan), pp. 145-153.

Seyfried, W. E., and Bischoff, J. L., 1979. Low temperature basalt alteration by sea water: An experimental study at $70^{\circ} \mathrm{C}$ and $150^{\circ} \mathrm{C}$. Geochim. Cosomochim. Acta, 43:1937-1947.

Shawney, B. L., 1967. Interstratification of vermiculite. Clays Clay Miner., 17:347-354.

Shepherd, T. J., Beckinsale, R. D., Rundel, C. C., and Durham, J., 1976. Genesis of Carrock Fell tungsten deposit, Cumbria: Fluid inclusion and isotopic study. Trans. Inst. Min. Metall., 85:B63-B73.

Steiger, R. H., and Jäger, E., 1977. Subcommission on geochronology: Convention on the use of decay constants in geo- and cosmochronology. Earth Planet. Sci. Lett., 36:359-362.

Sturt, B. A., Dalland, A., and Mitchell, J. G., 1979. The age of the sub mid-Jurassic tropical weathering profile of Andoya, Northern Norway, and the implications for the Late Palaeozoic paleogeography in the North Atlantic region. Geol. Rundschau, 68:523-542.

Terrell, D. J., 1982. Noble gas patterns in terrestrial igneous rocks [Ph.D. dissert.]. University of Newcastle upon Tyne, England.

Terrell, D. J., and Mitchell, J. G., 1983. Inert-gas contents of altered samples from Deep Sea Drilling Project Holes 501, 504B, and 505B, Costa Rica Rift. In Cann, J. R., Langseth, M. G., Honnorez, J., Von Herzen, R. P., White, S. M., et al., Init. Repts. DSDP, 69: Washington (U.S. Govt. Printing Office), 651-655.

Date of Initial Receipt: 23 August 1983

Date of Acceptance: 29 September 1983 